\title{
Measurement of the occupational risk level specific to workplaces
}

\author{
Angelica-Nicoleta Călămar ${ }^{*}$, Sorin Simion $^{1}$, Marius Kovacs $^{1}$, Alexandru Simion ${ }^{1}$ \\ ${ }^{1}$ National Institute for Research and Development in Mine Safety and Protection to Explosion - \\ INSEMEX Petroşani, 32-34 G-ral Vasile Milea Street, Postcode: 332047, Petroşani, Hunedoara \\ County, Romania
}

\begin{abstract}
Any workplace implies a greater or lesser number of occupational hazards, respectively workers are exposed to occupational risks, putting their health in danger. If we talk about industrial environments (construction, energy, metallurgy, textiles, wood, etc.), these hazards are found to a greater extent, often exceeding the allowable limit, but occupational pollutants such as dust in suspension and microclimate parameters can also be found in offices, whether they are open space or not. In this sense, the current paper reviews some workplaces and quantifies the level of risk to which workers are exposed to show and demonstrate the importance of occupational health prevention in order not to reach further measures, in time, when these occupational diseases occur. The research conducted led to the conclusion that the determined pollutants (dust, gas, microclimate) exceeded the maximum allowable concentration required by national legislation, both at workplaces in various technological flows and in offices. The high concentrations found in offices are caused by staff traffic, large number of employees, as well as the lack of natural ventilation.
\end{abstract}

\section{Introduction}

Occupational health requires multidisciplinary research to prevent health damage that may result from excessive, acute, or chronic exposure to chemicals. Early detection of harmful exposures can significantly reduce the occurrence of adverse effects by reducing exposure level and by taking precautionary measures. Exposure monitoring is a procedure that consists of routine assessment and interpretation of biological and/or environmental parameters in order to detect possible health risks $[1,2]$.

Work capacity and workers' health are influenced by nature of work, its regulation, relationships between work teams and structure of jobs. Ensuring the health of workers exposed to occupational hazards is an important goal in increasing the quality of life.

The occupational environment in which the worker's activity takes place is characterized by complex interaction of specific physical-chemical factors that can negatively influence the health of employees. These factors (microclimate parameters, toxic substances,

* Corresponding author: angela.calamar@insemex.ro 
suspended dust, noise, inadequate lighting, etc.) are also called harmful or dangerous factors [3].

Along with the dangerous and harmful factors, working conditions are determined by technological processes, the core business of workers or the type of work.

To quantify the level of occupational risk, a number of economic sectors were selected, namely, physical-chemical analysis laboratory, steel plant, automotive and IT activities. Investigation of selected objectives involved gathering information related to work environment, choosing the dominant toxins, choosing the appropriate equipment and working methods, taking samples, analysing and interpreting these samples.

Occupational risk assessment is a tool that demonstrates the application of prevention principles at company/enterprise level [4]. This means that any company must anticipate the dangers that can lead to accidents at work or occupational diseases, instead of reacting after such events have taken place. An essential step in implementing a responsible approach to occupational health and safety is occupational risk assessment.

\section{Investigating working conditions}

To investigate a workplace, it is necessary to: have knowledge of the technological process, choose the pollutants, sample assays, analyse and interpret data. To quantify the level of pollution of workplace atmosphere, the measured concentrations are related to the legislation in force, respectively GD 359/2015 and GD 157/2020 [3].

In case of simultaneous presence of several noxious substances, their action and interaction will be taken into account both from an analytical point of view and especially in terms of their action upon the human body (synergism by addition or potentiation, antagonism, etc.) [5, 6]. In choosing the noxious substances, both the raw material used in technological flows and possible impurities that it may contain, were taken into account. Exact knowledge of the noxious substances action upon humans, as well as their virulence are very important things, because the noxious substances collecting system and the method of determination chosen can largely depend on them.

In the industrial environment, the main way toxic substances penetrate the body is the respiratory tract ( $80-90 \%$ of occupational poisonings occur in this way), followed by transcutaneous and gastrointestinal paths $[5,7,8]$.

In work places, the microclimate is influenced by regional climate and its variations, but it depends, first of all, on the heat sources, the heating and the ventilation found inside. Microclimate conditions in workplaces must ensure the maintenance of human body's thermal balance, in accordance with the activity carried out.

Unfavourable microclimate is defined as the set of microclimate factors whose combined action exceeds the adaptive capacity of the body, overloading the thermoregulation system in order to maintain thermal balance. Strains upon the thermoregulation system generate thermal stress $[9,10]$.

\section{Methodology for determining occupational hazards}

Determination of occupational hazards and microclimate parameters in the work environment was performed in accordance with test procedures of the Toxicology Laboratory within INCD INSEMEX, authorized by the Ministry of Health, Public Health and Public Health Control.

Determination of respirable dusts in the work environment is performed gravimetrically, according to SR EN 689/2018 and STAS 10813/76. The principle consists in retaining dust 
on an FM membrane filter by passing a determined volume of air. The sampling assembly retains coarse dust from total dust, allowing the breathable fraction to pass through the filter.
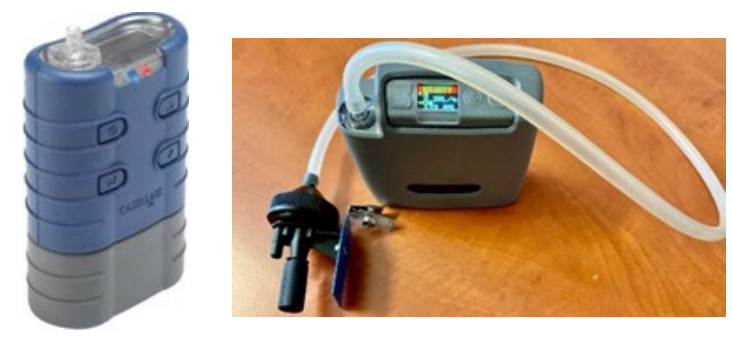

Fig. 1. Sampling probes (air flow meters) type TUFF

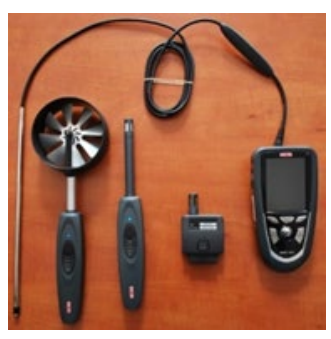

Fig. 2. AMI 300 device for determining microclimate parameters

For performing noise tests, the integrating sound level meter type 2250 was used, with 4189 type microphone and weighting networks A, C and Z. To determine the weighted sound exposure $\mathrm{A}$ and/or the equivalent continuous A-weighted sound pressure level, the measurements were performed with the microphone placed in the position normally occupied by the worker's head.

To determine the microclimate parameters, the AMI 300 device (Fig. 2.) from INCD INSEMEX Petrosani was used, which is a multifunctional instrument for measuring temperature (in the range of $-20 \div+80^{\circ} \mathrm{C}$ ), humidity (in the range of $3 \div 98 \%$ ) and air velocity (in the range of $0.2 \div 30 \mathrm{~m} / \mathrm{s}$ ), and measuring gaseous pollutants, both portable gas analysers with electrochemical sensors (MSA ORION plus) and the Optima 2100 DV inductive coupled plasma atomic emission spectrometer were used.

\section{Results and discussion}

During 2019, the team of the Toxicology Laboratory within INCD INSEMEX carried out several measurement campaigns (table 1.) at different economic agents, having different objects of activity. The current paper summarizes results found in several economic sectors (physical-chemical analysis laboratory, steel plant, automotive and IT activities) regarding the determination of pollutants in workplaces, to emphasize the importance of annually checks performed for these pollutants, so that employers are be able to take measures prevent or reduce noxae, where appropriate. 
Table 1. Determination of occupational hazards in the work environment

\begin{tabular}{|c|c|c|c|c|c|c|c|c|}
\hline \multirow{2}{*}{$\begin{array}{l}\text { N } \\
\text { o. }\end{array}$} & \multirow{2}{*}{$\begin{array}{l}\text { Economi } \\
\text { c sector }\end{array}$} & \multirow{2}{*}{$\begin{array}{c}\text { Work } \\
\text { area / } \\
\text { technologi } \\
\text { cal } \\
\text { operation }\end{array}$} & \multirow{2}{*}{$\begin{array}{c}\text { Determi } \\
\text { ned } \\
\text { noxae }\end{array}$} & \multirow{2}{*}{$\begin{array}{c}\text { Measuri } \\
\text { ng unit }\end{array}$} & \multicolumn{2}{|c|}{$\begin{array}{c}\text { Average } \\
\text { determined } \\
\text { concentrati } \\
\text { on } \\
\end{array}$} & \multirow{2}{*}{$\begin{array}{c}\text { Max. } \\
\text { allowable } \\
\text { concentrat } \\
\text { ion } \\
\text { according } \\
\text { to GD } \\
\text { 157/2020, } \\
\text { GD } \\
\text { 493/2006 }\end{array}$} & \multirow{2}{*}{$\begin{array}{c}\text { Observati } \\
\text { ons }\end{array}$} \\
\hline & & & & & $\begin{array}{c}15 \\
\text { mi } \\
\text { n. }\end{array}$ & $\begin{array}{c}8 \\
\text { ore }\end{array}$ & & \\
\hline \multirow[t]{19}{*}{1.} & \multirow[t]{19}{*}{$\begin{array}{l}\text { Steel } \\
\text { plant }\end{array}$} & $\begin{array}{l}\text { Electrical } \\
\text { furnace }\end{array}$ & \multirow{4}{*}{$\begin{array}{c}\text { Breathabl } \\
\text { e dust in } \\
\text { suspensio } \\
n\end{array}$} & $\begin{array}{c}{[\mathrm{mg} /} \\
\mathrm{m} 3]\end{array}$ & - & $\begin{array}{c}13,8 \\
1\end{array}$ & 5 & \multirow{8}{*}{$\begin{array}{c}\text { The } \\
\text { activity } \\
\text { takes place } \\
\text { in closed } \\
\text { halls } \\
\text { without } \\
\text { the } \\
\text { possibility } \\
\text { of optimal } \\
\text { retention / } \\
\text { exhaust of } \\
\text { dust } \\
\text { generated } \\
\text { by } \\
\text { technologi } \\
\text { cal } \\
\text { processes. }\end{array}$} \\
\hline & & $\begin{array}{c}\text { Pot } \\
\text { preparatio } \\
\text { n cast }\end{array}$ & & $\begin{array}{c}{[\mathrm{mg} /} \\
\mathrm{m} 3]\end{array}$ & - & 6,41 & 5 & \\
\hline & & $\begin{array}{l}\text { Crane } \\
\text { cabin } \\
\text { rolling } \\
\text { bridge }\end{array}$ & & $\begin{array}{l}{[\mathrm{mg} /} \\
\mathrm{m} 3]\end{array}$ & - & 8,16 & 5 & \\
\hline & & $\begin{array}{c}\text { Flue Gas } \\
\text { Capture } \\
\text { and } \\
\text { Treatment } \\
\text { Plant } \\
\end{array}$ & & $\begin{array}{l}{[\mathrm{mg} /} \\
\mathrm{m} 3]\end{array}$ & - & 8,59 & 5 & \\
\hline & & $\begin{array}{c}\text { Electrical } \\
\text { furnace }\end{array}$ & \multirow{4}{*}{ Noise } & $\mathrm{dB}(\mathrm{A})$ & - & $\begin{array}{c}103 \\
4\end{array}$ & 87 & \\
\hline & & $\begin{array}{c}\text { Pot } \\
\text { preparatio } \\
\text { n cast }\end{array}$ & & $\mathrm{dB}(\mathrm{A})$ & - & 89,8 & 87 & \\
\hline & & $\begin{array}{l}\text { Crane } \\
\text { cabin } \\
\text { rolling } \\
\text { bridge }\end{array}$ & & $\mathrm{dB}(\mathrm{A})$ & - & 83,3 & 75 & \\
\hline & & $\begin{array}{l}\text { Flue Gas } \\
\text { Capture } \\
\text { and } \\
\text { Treatment } \\
\text { Plant }\end{array}$ & & $\mathrm{dB}(\mathrm{A})$ & - & 87,7 & 87 & \\
\hline & & \multirow{3}{*}{$\begin{array}{l}\text { Electrical } \\
\text { furnace }\end{array}$} & $\mathrm{CO}$ & [ppm] & 29 & - & 26 & \multirow{11}{*}{$\begin{array}{c}\text { The } \\
\text { activity of } \\
\text { the } \\
\text { evaluated } \\
\text { Sections is } \\
\text { carried out } \\
\text { in closed } \\
\text { halls } \\
\text { without } \\
\text { the } \\
\text { possibility } \\
\text { of an } \\
\text { optimal } \\
\text { retention / } \\
\text { exhaust of }\end{array}$} \\
\hline & & & $\mathrm{CO}_{2}$ & [ppm] & $\begin{array}{c}642 \\
0\end{array}$ & - & 5000 & \\
\hline & & & $\begin{array}{l}\text { Ferric } \\
\text { oxide }\end{array}$ & $\begin{array}{c}\mathrm{mg} / \\
\mathrm{m} 3]\end{array}$ & 7 & - & 10 & \\
\hline & & \multirow{3}{*}{$\begin{array}{c}\text { Pot } \\
\text { preparatio } \\
\text { n cast }\end{array}$} & $\mathrm{CO}$ & {$[\mathrm{ppm}]$} & 10 & - & 26 & \\
\hline & & & $\mathrm{CO}_{2}$ & [ppm] & 540 & - & 5000 & \\
\hline & & & $\begin{array}{l}\text { Ferric } \\
\text { oxide }\end{array}$ & $\begin{array}{c}{[\mathrm{mg} /} \\
\mathrm{m} 3]\end{array}$ & 1,2 & - & 10 & \\
\hline & & \multirow{3}{*}{$\begin{array}{c}\text { Flame } \\
\text { cutting } \\
\text { machine }\end{array}$} & $\mathrm{CO}$ & [ppm] & 14 & - & 26 & \\
\hline & & & $\mathrm{CO}_{2}$ & [ppm] & 542 & - & 5000 & \\
\hline & & & $\begin{array}{l}\text { Ferric } \\
\text { oxide }\end{array}$ & $\begin{array}{c}{[\mathrm{mg} /} \\
\mathrm{m} 3]\end{array}$ & 7,6 & - & 10 & \\
\hline & & \multirow{2}{*}{$\begin{array}{c}\text { Distributio } \\
\mathrm{n} \text { room }\end{array}$} & $\mathrm{CO}$ & [ppm] & 2 & - & 26 & \\
\hline & & & $\mathrm{CO}_{2}$ & [ppm] & 479 & - & 5000 & \\
\hline
\end{tabular}




\begin{tabular}{|c|c|c|c|c|c|c|c|c|}
\hline & & & $\begin{array}{l}\text { Ferric } \\
\text { oxide }\end{array}$ & $\begin{array}{c}{[\mathrm{mg} /} \\
\mathrm{m} 3]\end{array}$ & 4,2 & - & 10 & $\begin{array}{l}\text { the gases } \\
\text { generated } \\
\text { by the } \\
\text { technologi } \\
\text { cal } \\
\text { processes. }\end{array}$ \\
\hline \multirow[t]{5}{*}{2.} & \multirow[t]{5}{*}{$\begin{array}{l}\text { Automot } \\
\text { ive }\end{array}$} & $\begin{array}{l}\text { Sandblasti } \\
\text { ng section }\end{array}$ & \multirow{2}{*}{$\begin{array}{c}\text { Breathabl } \\
\text { e dust in } \\
\text { suspensio } \\
n\end{array}$} & $\begin{array}{c}{[\mathrm{mg} /} \\
\mathrm{m} 3]\end{array}$ & - & 3,25 & 5 & \multirow{5}{*}{$\begin{array}{c}\text { Activity } \\
\text { carried out } \\
\text { in halls, } \\
\text { with } \\
\text { permanentl } \\
\text { y } \\
\text { controlled } \\
\text { temperatur } \\
\text { e and } \\
\text { humidity }\end{array}$} \\
\hline & & $\begin{array}{l}\text { Injection } \\
\text { moulding } \\
\text { machine }\end{array}$ & & $\begin{array}{c}{[\mathrm{mg} /} \\
\mathrm{m} 3]\end{array}$ & - & 1,33 & 5 & \\
\hline & & $\begin{array}{l}\text { Eccentric } \\
\text { press } 125 \mathrm{t}\end{array}$ & \multirow{3}{*}{ Noise } & $\mathrm{dB}(\mathrm{A})$ & - & 79,9 & 87 & \\
\hline & & $\begin{array}{l}\text { Eccentric } \\
\text { press } 80 \mathrm{t}\end{array}$ & & $\mathrm{dB}(\mathrm{A})$ & - & 88,0 & 87 & \\
\hline & & $\begin{array}{l}\text { Hydraulic } \\
\text { press } 60 \mathrm{t}\end{array}$ & & $\mathrm{dB}(\mathrm{A})$ & - & 72,8 & 87 & \\
\hline \multirow[t]{4}{*}{3.} & \multirow{4}{*}{$\begin{array}{c}\text { Physical- } \\
\text { chemical } \\
\text { analysis } \\
\text { laborator } \\
\text { y }\end{array}$} & $\begin{array}{l}\text { Physical- } \\
\text { chemical }\end{array}$ & $\mathrm{HCl}$ & $\begin{array}{c}{[\mathrm{mg} /} \\
\mathrm{m} 3]\end{array}$ & 4,96 & - & 8 & \multirow{4}{*}{$\begin{array}{c}\text { Industrial } \\
\text { ventilation } \\
\text { system }\end{array}$} \\
\hline & & $\begin{array}{l}\text { analysis } \\
\text { laboratory }\end{array}$ & $\mathrm{NO}_{2}$ & $\begin{array}{c}{[\mathrm{mg} /} \\
\mathrm{m} 3]\end{array}$ & 7,04 & - & 5 & \\
\hline & & $\begin{array}{c}\text { Furnace } \\
\text { room }\end{array}$ & $\mathrm{Pb}$ & $\begin{array}{c}\mathrm{mg} / \\
\mathrm{m} 3]\end{array}$ & - & $\begin{array}{c}0,32 \\
9 \\
\end{array}$ & 0,15 & \\
\hline & & $\begin{array}{c}\text { Weighing } \\
\text { room - } \\
\text { Document } \\
\text { ary tests }\end{array}$ & $\mathrm{Pb}$ & $\begin{array}{c}{[\mathrm{mg} /} \\
\mathrm{m} 3]\end{array}$ & - & $\begin{array}{c}0,46 \\
8\end{array}$ & 0,15 & \\
\hline \multirow[t]{7}{*}{4.} & \multirow{7}{*}{$\begin{array}{c}\text { Carpentr } \\
\text { y } \\
\text { worksho } \\
\text { p - wood } \\
\text { parts } \\
\text { treatment }\end{array}$} & \multirow[t]{3}{*}{$\begin{array}{c}\text { Oiling } \\
\text { wood parts }\end{array}$} & Toluene & $\begin{array}{c}{[\mathrm{mg} /} \\
\mathrm{m} 3]\end{array}$ & 458 & - & 384 & \multirow{7}{*}{$\begin{array}{c}\text { Inefficient } \\
\text { ventilation } \\
\text { system }\end{array}$} \\
\hline & & & Xylene & $\begin{array}{c}{[\mathrm{mg} /} \\
\mathrm{m} 3]\end{array}$ & 371 & - & 442 & \\
\hline & & & Acetone & $\begin{array}{c}\mathrm{mg} / \\
\mathrm{m} 3]\end{array}$ & $\begin{array}{c}121 \\
0\end{array}$ & - & 1210 & \\
\hline & & \multirow[t]{4}{*}{$\begin{array}{l}\text { Varnishing } \\
\text { room }\end{array}$} & Toluene & $\begin{array}{c}{[\mathrm{mg} /} \\
\mathrm{m} 3]\end{array}$ & 96 & - & 384 & \\
\hline & & & Xylene & $\begin{array}{c}\mathrm{mg} / \\
\mathrm{m} 3]\end{array}$ & 266 & - & 442 & \\
\hline & & & Acetone & $\begin{array}{c}\mathrm{mg} / \\
\mathrm{m} 3]\end{array}$ & $\begin{array}{c}285 \\
4 \\
\end{array}$ & - & 1210 & \\
\hline & & & $\begin{array}{c}\text { Ethyl } \\
\text { alcohol }\end{array}$ & $\begin{array}{c}\mathrm{mg} / \\
\mathrm{m} 3]\end{array}$ & 652 & - & 9500 & \\
\hline \multirow[t]{5}{*}{5.} & \multirow[t]{5}{*}{$\begin{array}{c}\text { IT } \\
\text { activities }\end{array}$} & \multirow[t]{5}{*}{$\begin{array}{l}\text { Offices } \\
\text { (open } \\
\text { space) }\end{array}$} & $\begin{array}{c}\text { Breathabl } \\
\text { e dust in } \\
\text { suspensio } \\
n\end{array}$ & $\begin{array}{c}{[\mathrm{mg} /} \\
\mathrm{m} 3]\end{array}$ & - & 6,40 & 5 & \multirow{5}{*}{$\begin{array}{l}\text { Central air } \\
\text { conditioni } \\
\text { ng system }\end{array}$} \\
\hline & & & $\begin{array}{c}\text { Air } \\
\text { temperatu } \\
\text { re }\end{array}$ & {$[0 \mathrm{C}]$} & - & $\begin{array}{c}23,9 \\
5\end{array}$ & \multirow{4}{*}{ - } & \\
\hline & & & $\begin{array}{c}\text { Radiant } \\
\text { average } \\
\text { temperatu } \\
\text { re }\end{array}$ & {$[0 \mathrm{C}]$} & - & $\begin{array}{c}26,6 \\
8\end{array}$ & & \\
\hline & & & $\begin{array}{l}\text { Relative } \\
\text { humidity }\end{array}$ & {$[\%]$} & - & $\begin{array}{c}39,2 \\
5\end{array}$ & & \\
\hline & & & $\begin{array}{c}\text { Air flow } \\
\text { speed }\end{array}$ & {$[\mathrm{m} / \mathrm{s}]$} & - & $\begin{array}{c}0,18 \\
9\end{array}$ & & \\
\hline
\end{tabular}




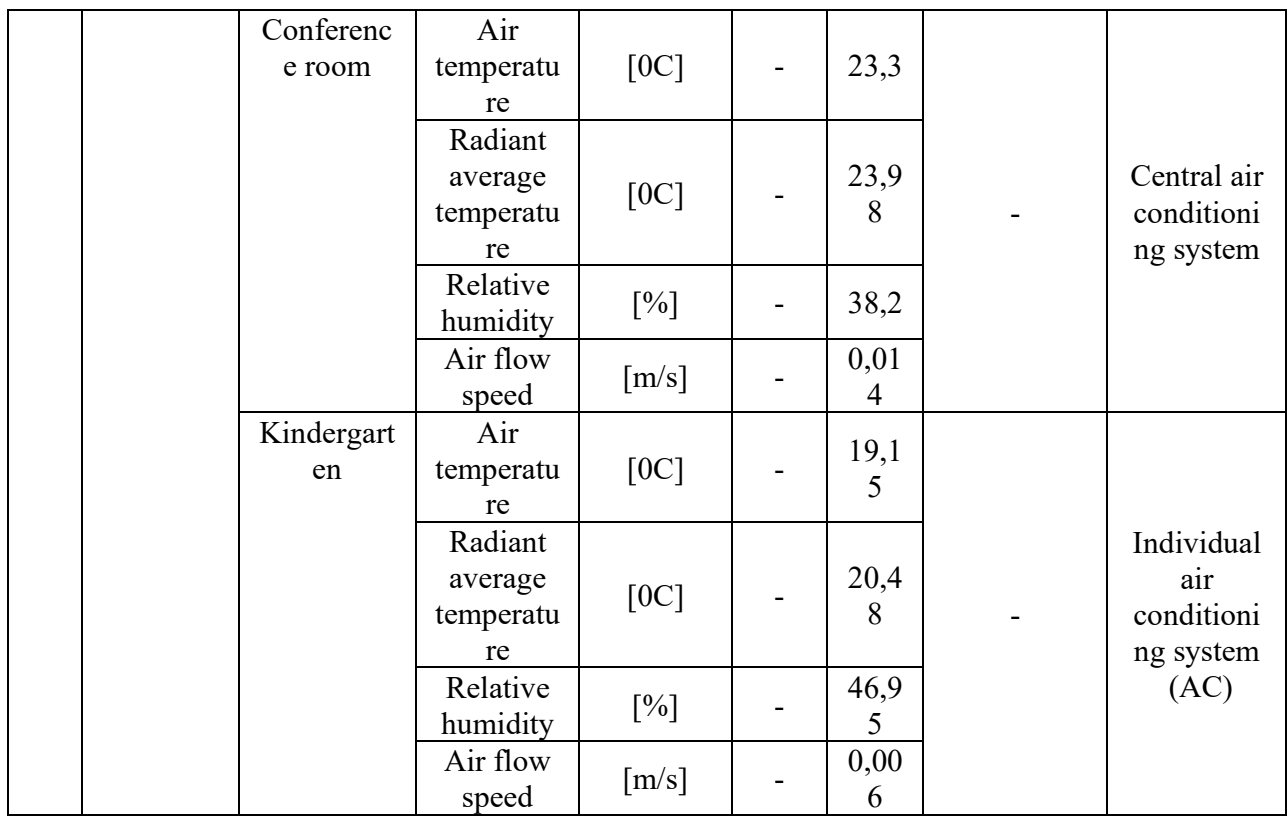

nalysis of results (table 1.) showed that in the steel plant activity sector, the maximum allowed limits for dust, noise and gas $\left(\mathrm{CO}\right.$ and $\left.\mathrm{CO}_{2}\right)$ are exceeded only in the electric furnace. In the activity carried out in the automotive section, there is a single exceeding of the noise level for the $80 \mathrm{t}$ press, and in the physical-chemical analysis laboratory there are exceedances for $\mathrm{Pb}$ and some volatile compounds.

Regarding the IT activity carried out in open space offices, values of dust in suspension concentration exceed the limit set by in force legislation, by $1.4 \mathrm{mg} / \mathrm{m}^{3}$.

According to the website of the European Agency for Safety and Health at Work (EUOSHA) regarding the limits for microclimate parameters, it is recommended that during warm periods of the year (when air cooling is required) temperature reaches $23-26^{\circ} \mathrm{C}$, and in cold periods of the year (when the air needs to be heated) the temperature should be in the range of $20-24^{\circ} \mathrm{C}$. Also, relative humidity of the air is recommended to be in the range of 30 $70 \%$ (avoiding, as much as possible, the limits of the range), and speed of the air currents in the room to be between $0.01-0.2$ THX.

PMV (Predicted mean vote) and PPD (Predicted percentage dissatisfied) calculation indices were used to interpret data obtained from IT activities, and for this it was necessary to estimate the metabolic rate and clothing isolation indices:

- the metabolic rate index was estimated at 1.2, which represents the specific value of office activity (offices, schools, laboratories, housing);

- the insulation index of daily clothing was estimated at 1 , which represents the specific value for clothing: shoes, trousers, blouse or shirt, socks and underwear to which 0.1 is added, represented by the index of the office chair.

In kindergarten, the calculated value of PPD is $6.28 \%$ (fig. 3.), which represents the percentage of people dissatisfied with microclimate parameters of the work environment, and the PMV value indicates a "cool" work environment. 


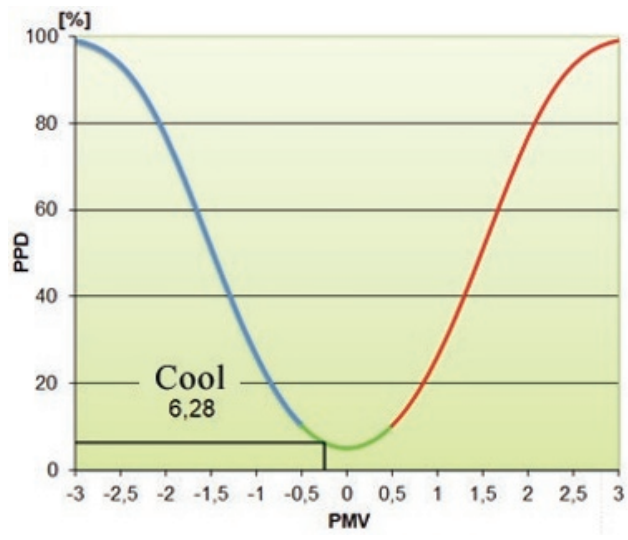

Fig.3. Graphic representation of the PMV and PPD index in kindergarten

Therefore, the analysed work environments are in line with the activities carried out (low energy consumption activities - office work and children's playgrounds), keeping a thermal balance between the internal heat production of the human body and heat loss in the work environment.

In conclusion, in the work environment where microclimate parameters were determined, $6.28 \%$ of the employed staff could be dissatisfied with the microclimate conditions, which proves the microclimate is favourable for development of office activities and education of children, but to increase the PMV index to a warmer environment it is recommended to increase the temperature in the work environment.

For a full understanding of the specific terminology in accordance with SR EN ISO 7730: 2006, the terms PPD and PMV are defined below.

PMV (Predicted mean vote) - is an index that predicts the average value of the votes of a large group of people on the thermal sensation scale.

PPD (Predicted percentage dissatisfied) - is an index that establishes a quantitative prediction of the percentage of thermally dissatisfied people who feel the work environment is too cold or too hot.

\section{Conclusions}

Concentrations of noxious substances (dust, gas, noise) from the analysed workplaces exceed the limit allowed by the legislation in force, especially in the steel sector. Also, values of respirable dust concentration in the IT sector - offices, exceed the maximum limit allowed by the applicable legislation. In this case, a number of technical and organizational measures are recommended, including replacement of existing carpeting in the workspace with parquet or other flooring that does not retain dust, installation of ventilation systems so as to ensure efficient ventilation, periodic replacement of filters in the air conditioning system.

Environmental conditions (temperature, humidity, pressure, thermal environment and thermal stress) have a significant influence on work performance.

Analysis of results according to the thermal sensation felt by workers (according to SR EN ISO 7730: 2006), shows that in most workplaces it is "warm / warmish", except for the Kindergarten, where a "cool" thermal sensation is felt.

In order to reduce the percentage of people who are dissatisfied, from a thermal point of view, it is recommended to reduce temperature and increase humidity in work spaces where the thermal environment is described as "warm". Also, at the Kindergarten location where a "cool" thermal sensation is felt, it is recommended to increase temperature to an approximate value of $23 \div 26^{\circ} \mathrm{C}$. 
The case study showed that even in office work (multinational companies), there may be concentrations of noxious substances, especially dust, which exceed the allowable limit, creating discomfort for workers and affecting their health over time.

The risk assessment may include a justification by the employer that nature and extent of risks due to chemical agents do not require another detailed risk assessment, if occupational exposure limit values or national biological limit values are not exceeded.

The risk assessment and implicitly the determination of noxious substances are updated, in particular if there have been significant changes in the working conditions or when results of workers' health status surveillance make this necessary.

\section{References}

1. L. Cioca, R. Moraru, Occupational psychosocial risk management, "Lucian Blaga" University of Sibiu Publishing House, ISBN 978-973-739-924-3, (2010)

2. A. N. Calamar, L. Toth, D. Pupazan, Environmental protection and risk factor analysis, Focus Publishing House, Petrosani, ISBN 978-973-677-313-6, (2016)

3. DECISION no. 157 of February 27th, 2020 for the amendment of the Government Decision no. 1,218 / 2006 regarding the establishment of minimum occupational safety and health requirements for ensuring protection of workers against risks related to presence of chemical agents, as well as for modification and completion of the Government Decision no. 1,093 / 2006 on the establishment of minimum safety and health requirements for protection of workers from risks related to exposure to carcinogens or mutagens at work.

4. A. N. Calamar, G.A. Gaman, L. Toth; D. Pupazan, S. Simion, Assessment of workers' occupational exposure in the context of industrial toxicology, World multidisciplinary earth sciences symposium WMESS 2016, Prague, Czech Republic, September, Vol.44, Article number: 032004, ISSN 1755-1307, (2016)

5. Guide General aspects of industrial toxicology. Methods of analysis used in industrial toxicology, Ministry of Health - National Institute of Public Health, (2013)

6. R.I. Moraru, Safety and health at work: university treaty, Focus Publishing House, Petrosani, ISBN 978-973-677-272-6, (2013)

7. M. Kovacs, L. Toth, G. Ghetie, A. N. Draghici, V. Traian, L., Gheorghe Best management practices applied to prevent and reduce concentrations of dust and gases released from power plants, Environmental Engineering and Management Journal, July, vol.13, No.6, pg.1421-1458, ISSN 1582-9596, (2014)

8. R. Stanescu Dumitru, Harmful agents in the professional environment, Romanian Medical Life Publishing House - Bucharest, ISBN 978-973-160-013-0, (2008)

9. C. Lupu, A.N. Draghici, G. Ghetie, M. Kovacs, L. Toth, C. Ilie, The influence of microclimate parameters in workplace, Bulletin of the Polytechnic Institute of Iasi "Gheorghe Asachi" Technical University of Iasi, Fasc. 4, Ed. Polithnium, ISSN 1453-1690, (2013)

10. M. Nakielska, K. Pawlowski, Conditions of the Internal Microclimate in the Museum, Journal of Ecological Engineering, Vol. 21, Issue: 1, pg.205-209, (2020) 